\title{
Studies on Preparation of Rabri using Date Syrup as Sugar Substitute
}

\author{
Mayank Kaushik ${ }^{1}$, Chandra Prakash ${ }^{2}$, Lalit Kumar ${ }^{2}$ \\ ${ }^{1}$ M.Sc.4th semester student, Baba Farid Institute of Technology, Dehradun (U.K.)-248007, India \\ ${ }^{2,3}$ Assistant Professor, Department of Food Technology, Baba Farid Institute of Technology, Dehradun (U.K.)-248007 India
}

\begin{abstract}
This study shows the development of Date syrup based rabri which is a highly nutritious product due to combined nutrition of date and milk. Phoenix dactylifera is a very nutritional fruit which contain about two third sugars, one-quarter of water, cellulose, pectin, ash and vitamins. On the other hand Rabri also have very nutritive as it provide approx. is contains all milk benefits and high calories due to 7-8 percent sugar content. As naturally we are all born to like sugar and it provide large amount of energy for day to day life but sugar abusing is a bad habit which can lead to various serious health problems. Therefore, this study will be done to replace refined sugar with natural sugar of date. Various ratios of the date syrup has been taken pursue by the sensory evaluation. After getting a standard value of various parameter the final value was obtain Milk: date syrup (93:7). which was evaluated by 10 untrained panelist on the basis of 9 point hedonic scale and the Rabri samples were stored at refrigeration condition $\left(5^{\circ} \mathrm{C}\right)$. Analysis of samples were carried out at 5 days interval for physical chemical parameters.
\end{abstract}

Keywords: Milk, Date based Rabri, Sensory Evaluation, physical chemical analysis, storage

\section{Introduction}

Rabri is partially concentrated and sweetened milk product containing several layers of clotted cream (Malai). It is a milk based dessert product and quite popular in northern and eastern parts of the country. Traditionally, it is prepared by simmering of whole milk for a prolonged period and adding sugar after achieving the desired concentrations. While the milk is slowly evaporated (without being stirred) at simmering temperature in a Karahi over an open fire, pieces of skin which form on the surface of the milk are continuously broken up and moved to the cooler parts of the karahi. When the volume of milk has been considerably reduced to $1 / 5^{\text {th }}$, then sugar is added to it, and layers of clotted cream are immersed in the mixture and the finished product obtained by heating the whole mass for another short period. Based on the market survey, sensory and chemical attributes of rabri were evaluated and a standard method of manufacture for rabri was developed (Gayen and Pal, 1991 b). It involves standardization of buffalo milk to $6 \%$ fat, its simmering in a steam jacketed kettle at $90^{\circ} \mathrm{C}$, repeated removal of clotted cream (Malai) on the colder part of the kettle or to a separate container, when concentration of milk to three fold after removing about $100 \mathrm{gm}$ clotted cream from $1 \mathrm{~kg}$ milk then added sugar @ 6\% of initial milk to the concentrated milk. The clotted cream is finally added to the concentrated sweetened milk.

Rabri prepared by traditional method is unhygienic, nonuniform in quality, has low keeping quality and involves labour and energy intensive method of production (Chauhan at el; 2014). Consequently the cost of this product is usually very high. The percentage of moisture content ranged between 24.33 to $38.85 \%$, fat 16.23 to $22.55 \%$, protein 9.94 to $12.01 \%$, lactose/sucrose 27.08 to $43.72 \%$ and ash 2.09 to $2.84 \%$. Overall mean values were observed as $31.76 \pm 0.96 \%, \quad 19.42 \pm 0.33 \%, \quad 10.74 \pm 0.10 \%$, $35.82 \pm 0.99 \%$ and $2.43 \pm 0.03 \%$ for moisture, fat, protein, lactose/sucrose and ash respectively. Energy values of Rabri varied between 315.59 to $400.15 \mathrm{Kcal} / 100 \mathrm{~g}$ with an overall mean of $361.05 \pm 4.73 \mathrm{Kcal} / 100 \mathrm{~g}$ (Soomro A.H.;2008).

Phoenix dactylifera is a flowering plant of belonging to the palm family Arecaceae (Palmae).The name of date palm originates from its fruit; "phoenix" which means purple or red (fruit) and "dactylifera" refers to the finger-like appearance of the fruit bunch (Krueger R.R. and Chao. T. C., 2007). The development of date fruits is divided into three stages, Khalal, Rutab and Tamr. Khalal stage dates are immature with hard texture, yellow or red or pink color and has Total Soluble Solids (TSS) of 30-45 ${ }^{\circ}$ brix, astringent and edible and Rutab stage of dates are soften at the tip of the fruit, Reducing sugars in sugarcane of $55-60{ }^{\circ}$ Brix, free from astringency and edible while Tamr stage of dates are fully ripped with RSS of $60-84{ }^{\circ}$ Brix and edible. Dates are generally harvested at tamr stage that is comes after the development around TSS of $60-70{ }^{\circ}$ Brix that are edible at this stage.

Dates are known to be rich in carbohydrates $(80 \%)$ but quite low in protein $(2-3 \%)$. Date fruits (Tamr) contained moisture ranged from 10 to $22 \%$, total sugars 62 to $75 \%$, protein 2.2 to $2.7 \%$, fiber 5 to $8 \%$, fat 0.4 to $0.7 \%$, ash 3.5 to $4.2 \%$, total acidity 0.06 to $0.20 \%$, ascorbic acid 30.0 to $50.0 \mathrm{mg} \%$,on dry weight basis. Date fruit as a nutritive product contains sugar substances about (70.6-76.3\%), proteins (1.9-3\%), fat $(0.2-2.8 \%)$, minerals $(1.3 \%)$ and vitamins (El-Sharnouby1 G.A. at el; 2014). The fruit contained $32 \%$ glucose and $30 \%$ fructose, while the water-insoluble fibers of its flesh consisted of $49.9 \%$ lignin and $20.9 \%$ polysaccharides (Shafiei M. at el; 2010). The study conducted by Walid Alshahib W. \& Marshall R.J. (2003) the flesh of dates contains $0.2-0.5 \%$ oil, whereas the seed contains $7.7-9.7 \%$ oil and found that weight of the seed is $5.6-14.2 \%$ of the date. The fatty acids occur in both flesh and seed as according to the presence of saturated and unsaturated acids. The seeds containing 14 types of fatty acids, but only eight of these fatty acids are found in very low concentration in 


\section{International Journal of Science and Research (IJSR) \\ ISSN (Online): 2319-7064 \\ Index Copernicus Value (2013): 6.14 | Impact Factor (2015): 6.391}

the flesh. Unsaturated fatty acids include palmitoleic, oleic, linoleic and linolenic acids.

The date (Phoenix dactylifera) is a high-energy fruit, used by the people of Egypt, Arabian Gulf Peninsula and its neighboring region from thousand years. Dates are used to making cubes, paste, spread, powder (date sugar), jam, jelly, juice, syrup and vinegar or alcohol. Discolored and filtered date juice yields a clear invert sugar solution (El-Sohaimy S.A. and Hafez E.E; 2010). During date syrup manufacturing, fruits (Phoenix dactylifera L.) are mixed with a suitable amount of water and heating above $70^{\circ} \mathrm{C}$ for about $1 \mathrm{~h}$.

\section{Milk}

Milk is the secretion after complete milking of healthy animal, excluding that obtained within after 15 days of calving.

\section{Composition of Milk}

Milk differs widely in composition. All milks mostly contain the same kind of constituents, but in varying in amounts. Milk from cows shows greater variation than the other mixed herd milk. The variation is always greater in small herds than in large ones. In general, milk fat shows the greatest daily variation as compare to protein, followed by ash and sugar.

Chemical Composition of Milk of different species

\begin{tabular}{|c|c|c|c|c|c|}
\hline Name of species & Water & Fat & Protein & Lactose & Ash \\
\hline Buffalo & 84.2 & 6.6 & 3.9 & 5.2 & 0.5 \\
\hline Cow & 86.2 & 4.6 & 3.4 & 4.9 & 0.7 \\
\hline Goat & 86.5 & 4.5 & 3.5 & 4.7 & 0.8 \\
\hline
\end{tabular}

Source: Chemistry of Milk by Davies (1939).

\section{Material and Methods}

\section{Procurement and preparation \\ Date syrup}

Deseed the date fruit and take them in a wide shallow vessel $\&$ wash under running tap water. After that warm water approx. 3 to 4 times more than the weight of dates. Then soak the dates in hot water $\left(70^{\circ} \mathrm{C}\right)$ for $30-45$ minutes. Now with the help of hand blender make mash of dates and extract the dates water by straining using a cheese cloth. Squeeze out the date syrup completely. Discard the dates residue and collect the date syrup in Saucepan or karahi. Boil the dates syrup in a karahi until it becomes thick. Boiling of the date syrup till reach the of date syrup $53^{\circ}$ brix by measurement of the Refractometer. Keep the flame low to medium and stir it occasionally to avoid burning at the bottom. Switch off the flame and place in a cool condition for storage.

\section{Rabri}

The composition of rabri depends on the initial composition of milk, the degree of concentration of milk solids and the percentage of sugar added. Rabri is normally prepared by heating 3-4 $\mathrm{kg}$ of milk in a karahi over an open fire to simmering temperature $\left(85^{\circ} \mathrm{C}-90^{\circ} \mathrm{C}\right)$, and then maintaining the temperature by controlled heating. The milk is neither stirred nor allowed to boil. The surface of milk may be gently fanned to help the process of skin formation. A piece of the skin, about $3-4 \mathrm{~cm}^{2}$, is continuously broken with a thick wooden stick (or bamboo/ cane splints) and moved to the cooler parts of karahi. This procedure requires considerable skill and constant attention. Simultaneously, as slow evaporation reduces milk to about one-fifth of its original volume, 7-8 percent by volume date syrup is added to the milk and dissolved in it. The layers of skin collected on the karahi surface are then immersed in the mixture and the finished product obtained by gently heating the whole mass for another brief period. Buffalo milk or full cream milk is invariably used to produces a more creamy consistency and a higher yield.

\section{Experimental details}

In the present investigation, two experiments were carried out and the experiments details are furnished here under:

Formulation of different combination of date based rabri by taking different proportions of date syrup and milk.

By using the above rabri preparation method we prepared 4 samples $\mathrm{C}, \mathrm{E}, \mathrm{F}$ and $\mathrm{G}$ having date syrup and milk in different ratios (i.e. $\mathrm{C}=7.4: 92.6, \mathrm{E}=6.6: 93.4, \mathrm{~F}=7: 93$ and $\mathrm{G}=$ 6.8:93.2).

Storage study of Date based Rabri. Interval analysis: At 5 days interval till product get spoiled. Parameters: $\mathrm{pH}$, acidity, moisture, fat, protein, and sensory analysis. The following parameters were analyzed for the above combination of samples in fresh and stored condition $\left(5^{\circ} \mathrm{C}\right)$.

\section{Result and Discussion}

\section{Physico-Chemical changes of Date based Rabri During storage period.}

\subsection{Moisture Content:}

Variation in the present studies the moisture content of Rabri is observed in increasing order which is presented in the Fig no: 1 . The result revealed that the concentration of moisture in Rabri ranged $36 \%, 37.58 \%, 38.44 \%$ and $39.20 \%$ of sample $\mathrm{C}, \mathrm{E}, \mathrm{F}$ and $\mathrm{G}$ of the fresh sample respectively and on 20th day it will increased up to $50.65 \%, 52.36 \%, 52.68 \%$ and $53.41 \%$. However, the overall mean values of moisture obtained as $46 \pm 0.06,48 \pm 0.06,48 \pm 0.06$ and $49 \pm 0.05$ of sample $\mathrm{C}, \mathrm{E}, \mathrm{F}$ and $\mathrm{G}$ respectively. The data is nonsignificant as $p>0.05(p=0.90)$.

Table 1: Effect on moisture content(\%) during storage

\begin{tabular}{|c|c|c|c|c|}
\multicolumn{5}{c|}{ period. } \\
\hline Days & C & E & F & G \\
\hline 0 & 36 & 37.58 & 38.44 & 39.20 \\
\hline 5 & 45.88 & 47.56 & 47.20 & 48.20 \\
\hline 10 & 47.98 & 49.30 & 49.86 & 50.0 \\
\hline 15 & 49.54 & 51.08 & 51.18 & 52.16 \\
\hline 20 & 50.65 & 52.36 & 52.68 & 53.41 \\
\hline Mean & $46 \pm 0.06$ & $48 \pm 0.06$ & $48 \pm 0.06$ & $49 \pm 0.05$ \\
\hline
\end{tabular}




\section{International Journal of Science and Research (IJSR) \\ ISSN (Online): 2319-7064}

Index Copernicus Value (2013): 6.14 | Impact Factor (2015): 6.391

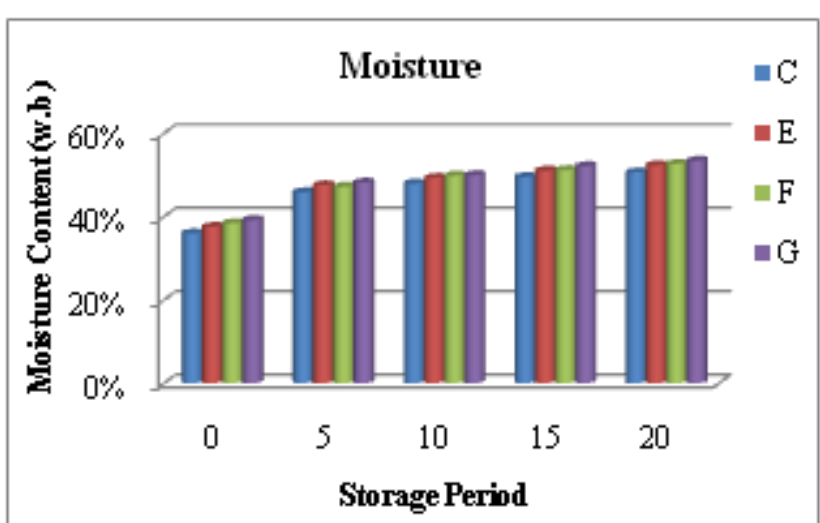

Figure 1: Changes in Moisture content during storage Period.

\section{$3.2 \mathrm{pH}$}

The $\mathrm{pH}$ of the Rabri samples were obtained as 7.64, 7.66, 7.64 and 7.64 for samples C, E, F and G. So as the storage time increases the $\mathrm{pH}$ of Date syrup based rabri decreases, on the 20th day $\mathrm{pH} 6.46,6.48,6.94$ and 6.42 was obtained. The $\mathrm{pH}$ having mean values $6.97 \pm 0.46,6.98 \pm 0.46$, $6.94 \pm 0.47$ and $7.06 \pm 0.47$, the values show non-significant data as $\mathrm{p}>0.05(\mathrm{p}=0.97)$.

Table 2: Effect on $\mathrm{pH}$ of different during storage

\begin{tabular}{|c|c|c|c|c|}
\hline Days & C & E & F & G \\
\hline $\mathbf{0}$ & 7.64 & 7.66 & 7.64 & 7.64 \\
\hline $\mathbf{5}$ & 7.18 & 7.15 & 7.1 & 7.32 \\
\hline $\mathbf{1 0}$ & 6.89 & 6.93 & 6.9 & 7.1 \\
\hline $\mathbf{1 5}$ & 6.68 & 6.68 & 6.64 & 6.83 \\
\hline $\mathbf{2 0}$ & 6.46 & 6.48 & 6.43 & 6.42 \\
\hline Mean & $6.97 \pm 0.46$ & $6.98 \pm 0.46$ & $6.94 \pm 0.47$ & $7.06 \pm 0.47$ \\
\hline
\end{tabular}

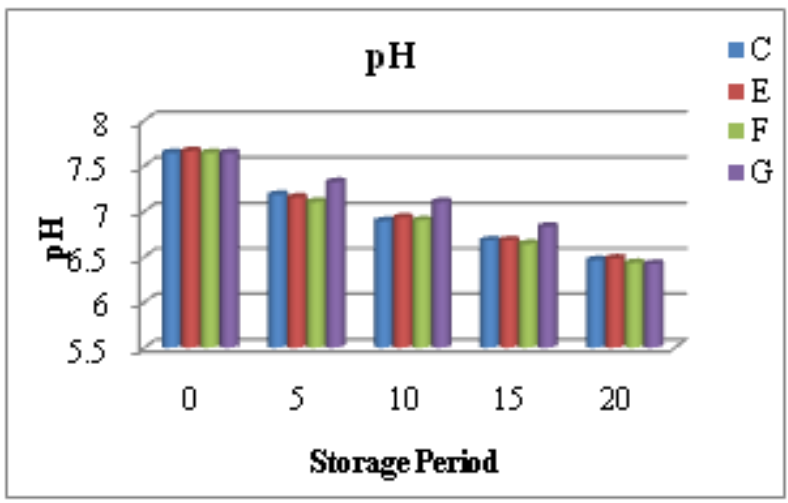

Figure 2: Changes in $\mathrm{pH}$ during storage period.

\subsection{Acidity}

The acidity of the Rabri samples was obtained as 0.054 , $0.078,0.068$ and 0.0837 for samples C, E, F and G. So as the storage time increases the acidity of Date syrup based rabri also increases, on the 20th day acidity was $0.44,0.457$, 0.452 and 0.468 was obtained. The acidity was having mean values $0.28 \pm 0.15,0.29 \pm 0.14,0.29 \pm 0.14$ and $0.30 \pm 0.15$, the values show non-significant data as $\mathrm{p}>0.05(\mathrm{p}=0.99)$.
Table 3: Effect on acidity of different during storage

\begin{tabular}{|c|c|c|c|c|}
\hline Days & C & E & F & G \\
\hline $\mathbf{0}$ & 0.05 & 0.07 & 0.06 & 0.08 \\
\hline $\mathbf{5}$ & 0.25 & 0.26 & 0.25 & 0.27 \\
\hline $\mathbf{1 0}$ & 0.26 & 0.29 & 0.28 & 0.29 \\
\hline $\mathbf{1 5}$ & 0.36 & 0.36 & 0.37 & 0.37 \\
\hline $\mathbf{2 0}$ & 0.44 & 0.45 & 0.45 & 0.46 \\
\hline Mean & $0.28 \pm 0.15$ & $0.29 \pm 0.14$ & $0.29 \pm 0.14$ & $0.30 \pm 0.15$ \\
\hline
\end{tabular}

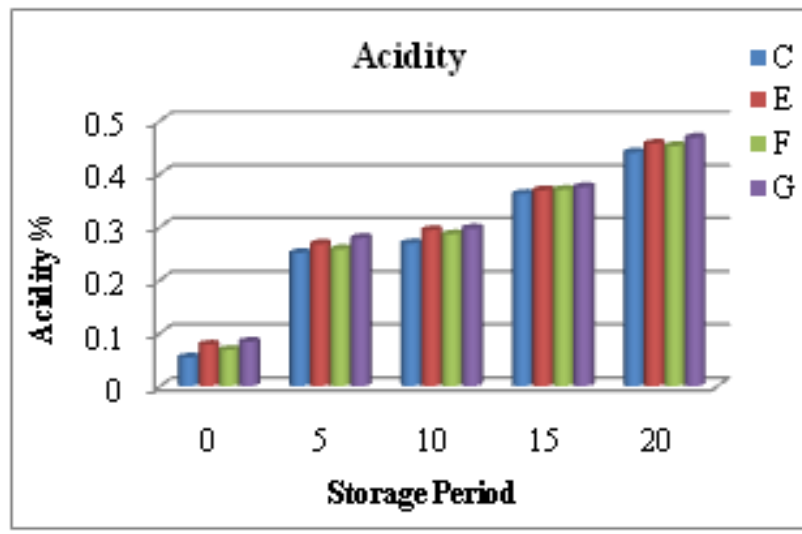

Figure 3: Changes in acidity during storage period.

\subsection{Ash}

The percentage of ash in Rabri samples 2.2, 2.1, 2 and 2.84 percent for fresh Rabri using date syrup as sugar substitute with an average of $2.18 \pm 0.04,2.1 \pm 0,2 \pm 0$ and $1.88 \pm 0.04$ for samples $\mathrm{C}, \mathrm{E}, \mathrm{F}$ and $\mathrm{G}$ respectively.

Table 4: Effect on Ash content of samples during storage

\begin{tabular}{|c|c|c|c|c|}
\hline Days & C & E & F & G \\
\hline $\mathbf{0}$ & 2.2 & 2.1 & 2 & 1.8 \\
\hline $\mathbf{5}$ & 2.2 & 2.1 & 2 & 1.9 \\
\hline $\mathbf{1 0}$ & 2.1 & 2.1 & 2 & 1.9 \\
\hline $\mathbf{1 5}$ & 2.2 & 2.1 & 2 & 1.9 \\
\hline $\mathbf{2 0}$ & 2.2 & 2.1 & 2 & 1.9 \\
\hline Mean & $2.18 \pm 0.04$ & $2.1 \pm 0$ & $2 \pm 0$ & $1.88 \pm 0.04$ \\
\hline
\end{tabular}

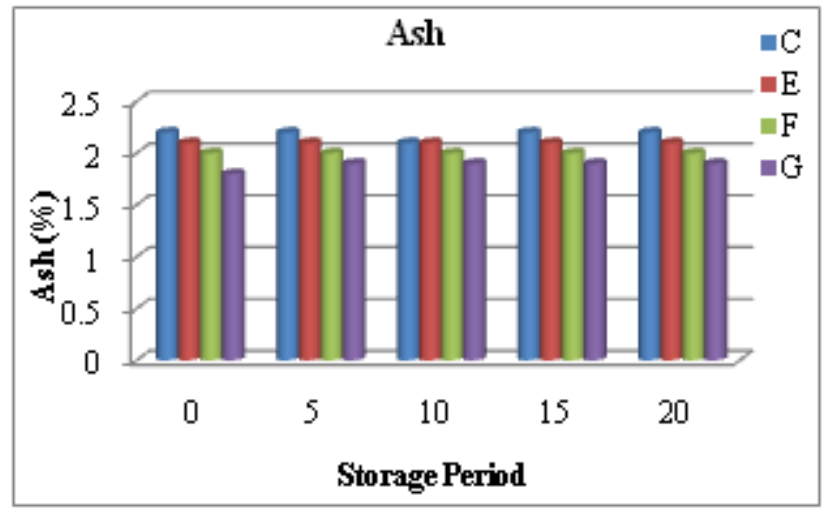

Figure 4: Changes in ash of product during storage period.

\subsection{Protein}

Rabri samples were evaluated for protein content and results are shown in Fig. 3. The percentage of protein content of fresh sample of Rabri using date syrup as sugar substitute was observed as $11.9,12.1,12.5$ and 13 percent for sample $\mathrm{C}, \mathrm{E}, \mathrm{F}$ and $\mathrm{G}$ which decreased to $8.8,8.9,9.1$ and 9.5 


\section{International Journal of Science and Research (IJSR) \\ ISSN (Online): 2319-7064 \\ Index Copernicus Value (2013): 6.14 | Impact Factor (2015): 6.391}

percent. The highest value of protein observed in the Sample $\mathrm{G}$ (93.2:6.8), this is the best product we have observed in during storage period of Date based Rabri. Moreover, the mean results of the study observed as $10.24 \pm 1.18,10 . \pm 1.33$, $10.74 \pm 1.4$ and $11.7 \pm 1.79$ percent with non significant data as $\mathrm{p}>0.05(\mathrm{p}=0.41)$.

Table 5: Effect on Protein \% of samples during storage

\begin{tabular}{|c|c|c|c|c|}
\hline Days & C & E & F & G \\
\hline $\mathbf{0}$ & 11.9 & 12.1 & 12.5 & 13 \\
\hline $\mathbf{5}$ & 10.8 & 11.4 & 11.8 & 13.5 \\
\hline $\mathbf{1 0}$ & 10.1 & 10.4 & 10.5 & 12.4 \\
\hline $\mathbf{1 5}$ & 9.6 & 9.4 & 9.8 & 10.1 \\
\hline $\mathbf{2 0}$ & 8.8 & 8.9 & 9.1 & 9.5 \\
\hline Mean & $10.24 \pm 1.2$ & $10.44 \pm 1.3$ & $10.74 \pm 1.4$ & $11.7 \pm 1.8$ \\
\hline
\end{tabular}

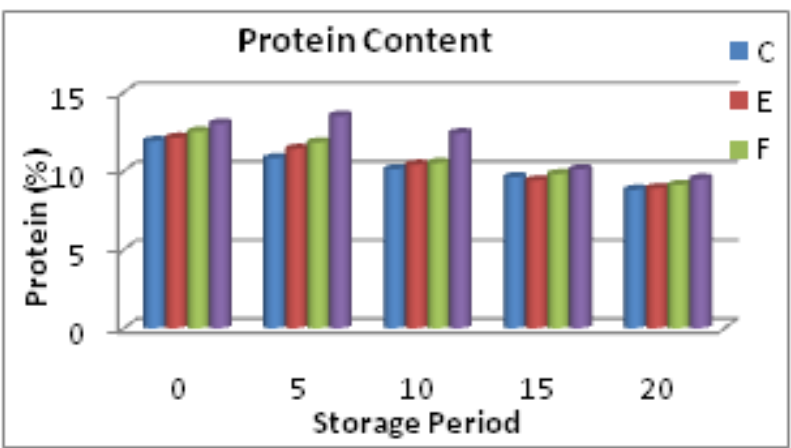

Figure 5: Changes in protein during storage period.

\subsection{Fat}

The concentration of fat in Rabri varied greatly 20.1, 20.9, 21.2 and 23.5 percent for the sample C, E, F and G for the fresh sample. On the last day of storage the fat value decreased to $17.1,17.6,17.9$ and 19.6 percent with mean value of $18.56 \pm 1.2,19.06 \pm 1.3,19.44 \pm 1.3$ and $21.3 \pm 1.5$ percent respectively. The $(\mathrm{p}=0.02)$ values show a significant result as $\mathrm{p}<0.05(\mathrm{p}=0.025)$.

Table 6: Effect on Fat \% of samples during storage.

\begin{tabular}{|c|c|c|c|c|}
\hline Days & C & E & F & G \\
\hline $\mathbf{0}$ & 20.1 & 20.9 & 21.2 & 23.5 \\
\hline $\mathbf{5}$ & 19.4 & 19.8 & 20.1 & 21.9 \\
\hline $\mathbf{1 0}$ & 18.4 & 18.9 & 19.4 & 21.1 \\
\hline $\mathbf{1 5}$ & 17.8 & 18.1 & 18.6 & 20.4 \\
\hline $\mathbf{2 0}$ & 17.1 & 17.6 & 17.9 & 19.6 \\
\hline Mean & $18.56 \pm 1.2$ & $19.06 \pm 1.3$ & $19.44 \pm 1.3$ & $21.3 \pm 1.5$ \\
\hline
\end{tabular}

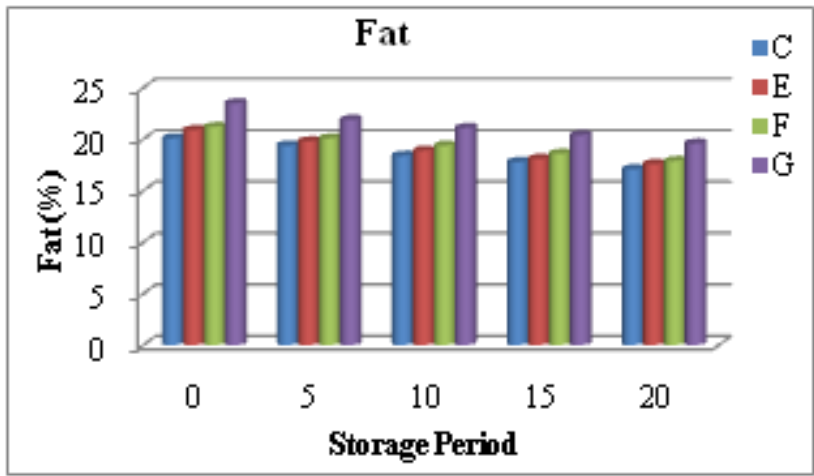

Figure 6: Changes in fat of the product during storage.

\section{Sensory Evaluation}

\subsection{Colour}

Data on appearance and colour in Date syrup Based Rabri is given in table. Change in colour and appearance was not significant up to 20 days of storage. Colour and appearance approximately same up to 20 days. Among the different ration of milk and date syrup Sample-G (93.2:6.8) was having higher score than other treatments.

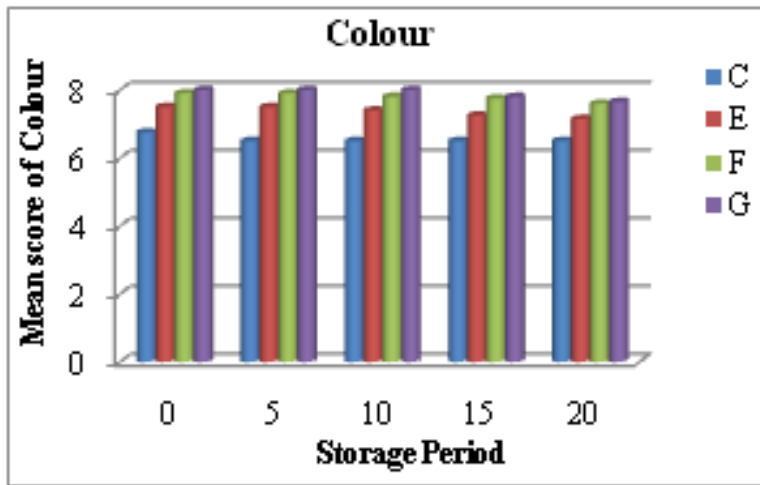

Figure 7: Sensory evaluation of Colour during storage period.

\subsection{Texture}

There had been non-significant changes in consistency of date base rabri during storage period (table). Consistency is decreased from 0day to 20days of storage. Higher consistency was observed in Sample-E (93.4:6.6), Sample-F (93:7) and Sample-G (93.2:6.8).

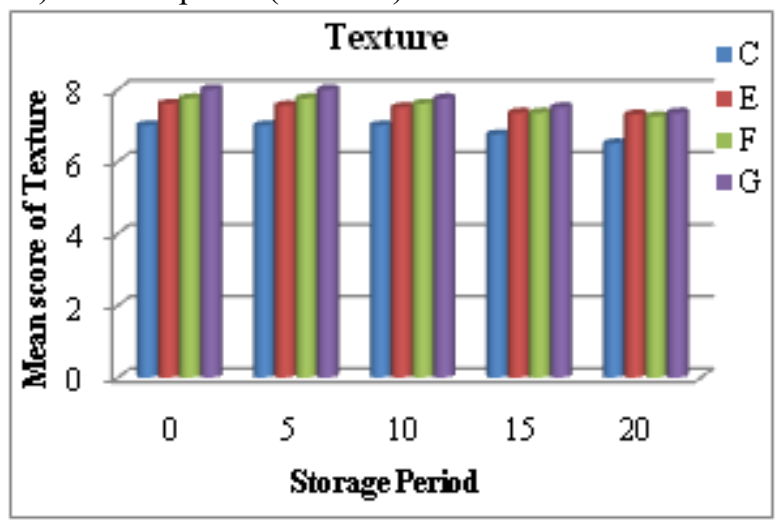

Figure 8: Sensory evaluation of Texture during storage period

\subsection{Flavour}

There were significant changes in flavour of Date syrup based Rabri during the storage period (table). Flavour is slightly changed from 0 day to 20days. Higher flavour were observed in Sample-G (93.2:6.8). 


\section{International Journal of Science and Research (IJSR) \\ ISSN (Online): 2319-7064}

Index Copernicus Value (2013): 6.14 | Impact Factor (2015): 6.391

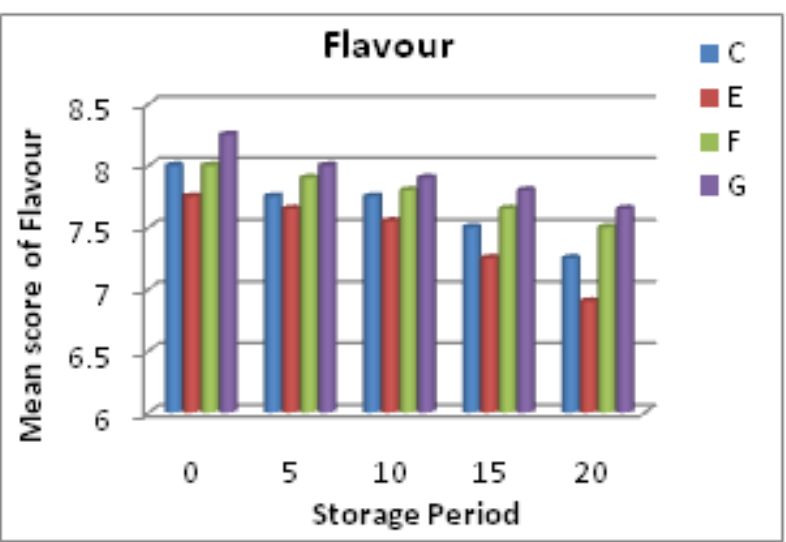

Figure 9: Sensory evaluation of Flavour during storage period.

\subsection{Sweetness}

The result in table. showed that the sweetness of Date syrup based rabri which changed during storage. The taste decreased from 0 day to 20 days. Sample-G (93.2:6.8) scored high compared to all others treatments and in balanced form.

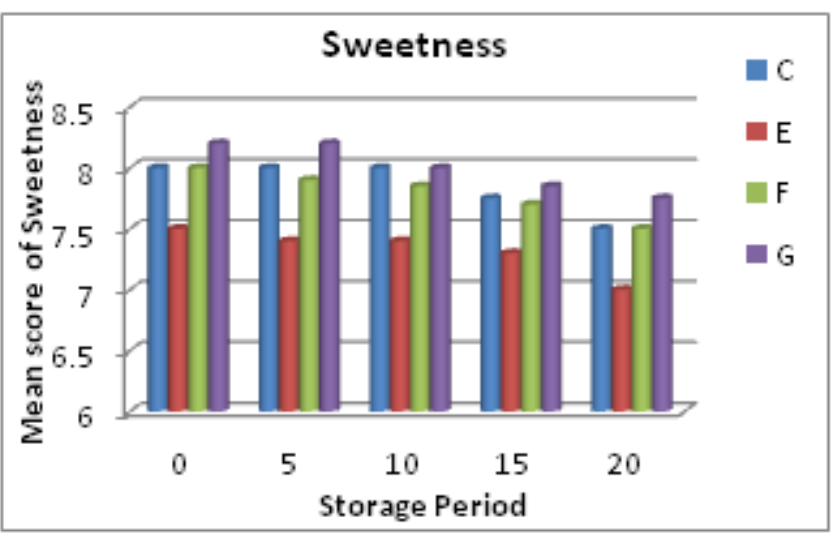

Figure 10: Sensory evaluation of Sweetness during storage period.

\section{Conclusions}

Milk is having high nutritive value as it contains fat and water soluble vitamins, minerals, proteins and lipids. On the other hand dates are also having high nutritive value as they are rich in carbohydrates, fiber, fat, ash. Date fruit as a nutritive product contains sugar, proteins, fat, minerals (boron, calcium, cobalt, copper, fluorine, iron, magnesium, manganese, potassium, phosphorous, sodium and zinc) and vitamins (of vit-C, and vit- $\mathrm{B}_{1}$ thiamine, $\mathrm{B}_{2}$ riboflavin, nicotinic acid (niacin) and vit-A). Combination of both provide a highly nutritive product with benefits of both.

The results are:

- Out of the three formulation (E, F and $G$ ) other than controlled (C), the sample-G is selected by the sensory panelists on the basis of sensory analysis.

- The changes observed in fresh sample during the storage time were decrease, $\mathrm{pH}$, acidity, fat, protein but the moisture keeps increasing.

- The scores for sensory attributes decrease on storage.
- The product can be stored at refrigeration temperature up to 16 days and can be consumed.

\section{References}

[1] Al-Taher Abdulla Y. (2008), Possible anti-diarrhoeal effect of the date palm (Phoenix Dactylifera L) spathe aquous extract in rats; Scientific journal of King Faisal University (Basic and Applied Sciences); vol.9, pp:131-138.

[2] Chandrasekaran M. and Ali H.B. (2013), Valorization of date palm (Phoenix dactylifera) fruit processing by-products and wastes using bioprocess technology, Saudi J Biol Sci. vol.20(2), pp: 105-120.

[3] Chauhan, A. S.; Yadav, M. P. S. and Gupta M. (2014), Effect of milk and sugar on physico-chemical qualities of rabri; Environment and Ecology; vol 32(4); pp:1404-1406.

[4] ChihCheng T.C. and Robert R.K. (2007), The Date Palm (Phoenix dactyliferaL.): Overview of Biology, Uses, and Cultivation, HortScience; vol.42, pp:10771082.

[5] El-Sharnouby G.A., Aleid S.M. and Al-Otaibi M.M. (2014), Liquid Sugar Extraction from Date Palm (Phoenix dactylifera $L_{\dot{.}}$ ) Fruits. J Food Process Technol; vol.5(12).

[6] Ghayal G., Jha A., Sahu J.K., Kumar A., Gautam A., Kumar R. and Rasane P. (2013), Moisture sorption isotherms of dietetic Rabri at different storage temperatures; Society of Dairy Technology; Vol.66; pp:587-594.

[7] Godson G Akunna, Chia L Saalu, Oluwaseyi S Ogunmodede, Babatunde Ogunlade and Aynomide J Bello (2012), Aqueous Extract of Date Fruit (Phoenix dactylifera) Protects Testis against Atrazineinduced Toxicity in Rat; World Life Science and Medical Research; vol.2(2), pp:100-108.

[8] James M. Rippe and Theodore J. Angelopoulos (2013), Sucrose, High-Fructose Corn Syrup, and Fructose, Their Metabolism and Potential Health Effects: What do we really know?; Advances in Nutrition: An International Review Journal; vol.4; pp:236-245.

[9] Leo Tjaderhane and Markku Larmas (2016), A High Sucrose Diet Decreases the Mechanical Strength Of Bones in Growing Rats; The journal of Nutrition; vol.128(10); pp:1807-1810.

[10] NDRI (2006), Developments in Traditional Dairy Products; vol.1, pp:23.

[11] Omar Ishurd and John F. Kennedy (2004), The anticancer activity of polysaccharide prepared from Libyan dates (Phoenix dactylifera L.); Carbohydrate Polymers; vol.59(4); pp:531-535.

[12] Pandey R.K., Govindam, Chaubey A.K., Chaubey C.S., and Verma S.P. (2004), Impact of sugar level on Rabri production, New Agriculturist, vol.15(1/2), pp:145-147.

[13] Rania M.A.M., Aisha S.M.F., Mohamed M.E. and Isam A.M.A. (2014), Chemical composition, antioxidant capacity, and mineral extractability of sudanese date palm (Phoenix dactylifera) fruit, Food Science and Nutrition, vol.2(5), pp:478-489. 


\section{International Journal of Science and Research (IJSR) \\ ISSN (Online): 2319-7064}

Index Copernicus Value (2013): 6.14 | Impact Factor (2015): 6.391

[14] S. Ranganna (1997), Handbook of Analysis and Quality Control for Fruits and Vegetable Products; second edition.

[15] Sukumar de (1991), Outlines of Dairy Technology.

[16] Walid Al-shahib \& Marshall R.J (2003), The fruit of the date palm: it's possible use as the best food for the future?; International Journal of Food Sciences and Nutrition; vol.54(4), pp: 247-259.

[17] Wan Ismail W.I. and Mohd Radzi M.N.F. (2013), Evaluation on the Benefits of Date Palm (Phoenix dactylifera) to the Brain, Altern Integ Med, vol.2(4).

[18] Gayen, D. and Pal, D. 1991a. Sensory, chemical and microbiological qualities of Delhi and Karnal market samples of Rabri. Indian J. Dairy Sci; vol.44(1), pp:80-83.

[19] Gayen, D. and Pal, D. 1991b. Studies on the manufacture and storage of rabri Indian J. Dairy Sci; vol.44(1), pp:84-88.

[20] Khaskhali A., Jamali A., Arain M.A., Nizamani A.H., Soomro A.H. and Arain H.H.(2008); Chemical and Sensory Quality of Indigenous Milk Based Product 'Rabri'; Pakistan Journal of Nutrition; vol.7(1), pp:133-136.

[21] El-Sohaimy S.A. and Hafez E.E. (2010); Biochemical and Nutritional Characterizations of Date Palm Fruits; Journal of Applied Sciences Research, vol.6(8), pp:1060-1067.

[22] Shafiei M., Karimi K. and Taherzadeh M.J.; Palm Date Fibers: Analysis and Enzymatic Hydrolysis; International Journal of Molecular Sciences; vol.11, pp: 4285-4296. 